2

3 Paul Jepson ${ }^{1,3^{*}}$, Ben Caldecott ${ }^{3}$, Suzanne F. Schmitt ${ }^{4}$, Sergio H. C. de Carvalho ${ }^{5}$, Ricardo A.

4 Correia $^{1,2}$, Ana C.M. Malhado ${ }^{2}$, Norah Gamarra ${ }^{2}$, Chiara Bragagnolo ${ }^{2}$, \& Richard J. Ladle ${ }^{1,2}$

5

6 1. School of Geography and the Environment, University of Oxford, South Parks Road,

7 Oxford OX1 3QY, UK.

8 2. Institute of Biological Sciences and Health, Federal University of Alagoas, Campus A. C.

9 Simões, Av. Lourival Melo Mota, s/n Tabuleiro dos Martins, Maceió, AL, Brazil.

\section{Protected Area Asset Stewardship}

3. Smith School of Enterprise and the Enviornment, University of Oxford, South Parks Road, Oxford OX1 3QY, UK.

4. WWF-UK, Living Planet Centre, Brewery Rd, Woking, GU21 4LL, UK

5. Ministry of the Environment of Brazil, Esplanada dos Ministérios, Bloco B Brasília, Brazil.

\section{Perspective article submitted to Biological Conservation perspective}

Words (including references) 7430 


\section{Abstract $(\max 150)$}

24 Protected areas (PAs) are the main strategy to conserve natural values and reduce biodiversity loss. However, with increasing global food requirements, using land for protecting landscapes and species is becoming increasingly difficult to justify. Here, we argue that framing PAs as spatial assets provides an ideal platform for generating investment and increasing their political/cultural resilience. Specifically, we define and characterize PAs in terms of their biophysical, human, infrastructure, institutional and cultural assets, making explicit the forms of value they create and for whom, and identifying types of investment needed to generate value in the medium and long term. These assets can be protected, managed and/or invested in to generate (monetizable and non-monetizable) forms of value. They can also be at risk from a variety of factors. Building on contemporary conservation policy, our asset framework provides an innovative approach to the development and management of PAs in the $21^{\text {st }}$ 35 Century.

\section{$37 \quad$ Keywords}

Protected Areas, Conservation Policy, Natural Assets, Natural Capital, Conservation values. 


\section{Introduction}

The creation of Protected Areas (PAs) for conserving attributes of nature over the long term was one of the defining features of the $20^{\text {th }}$ century (Jepson et al. 2011). Adopted as a policy strategy by virtually every country, PAs increased from a handful at the start of the $20^{\text {th }}$ Century to more than 162,000 legally designated (statutory) national PAs covering 28.4 million square kilometres by 2013 (Watson et al. 2014). PAs in their various forms have influenced societies across the globe and are the cornerstone of efforts to sustain the Earth's biodiversity and ecosystems. Despite their key role in biodiversity conservation, PAs are under increasing pressure to justify their existence in the face of competition with other land uses, especially agriculture (Geldmann et al. 2014; Laurance and Balmford 2013; Smith et al. 2010). This is because, depending on size and location, PAs can indirectly influence regional economies through land opportunity costs and/or the cost of mitigating the effects of linear infrastructure development (Symes et al. 2015). In a $21^{\text {st }}$ century of expanding human populations, struggling economies, increasing resource extraction, and expanding infrastructure, there is a significant risk that PAs will be seen by politicians as being 'in the way' of human development (Watson et al. 2014) or even 'green' land grabs (Fairhead et al. 2012).

That PAs may be losing traction as a policy ideal is supported by observations that some governments have back-tracked on international commitments, sometimes to the extent of ignoring their own policies and legislation (e.g. Swenson et al. 2011). Budgets for PA management are also being cut, even in rich countries with strong PA traditions such as Australia, the US, Canada and the UK (Watson et al. 2014). The phenomenon of PADDD (Protected Area Downgrading, Downsizing and Degazettement) is widespread and increasing in certain parts of the world (Bernard et al. 2014; Mascia et al. 2014; Pack et al. 2016; Symes et al. 2015).

In short, PAs are increasingly vulnerable to social and political pressures. In the light of these challenges, a key question for conservation policy and management is: how to increase the resilience of PAs in the changing and increasingly volatile socio-economic landscapes of the $21^{\text {st }}$ century?

Framing an issue for policy inevitably foregrounds particular worldviews, problems and solutions. Such framings and the scale of their adoption affects which interests gain influence and which professions and partnerships become involved in implementation. During the late 1980s biodiversity conservation became the dominant framing for PAs in policy dialogue, 
privileging conservation biology perspectives. However, difficulties in substantiating a biodiversity-value-beneficiary narrative may have contributed to perceptions in some circles that biodiversity conservation is an end in itself, thereby narrowing the opportunities for alignment between PA development and wider policy. Subsequently, the ecosystem services policy frame and the metaphor of nature as a fixed stock of capital that can sustain a supply of ecosystem services (Daley 1997) has more closely aligned conservation with economic development policy. Such a framing highlights the strongly utilitarian idea of "nature for people and the economy' (Norgaard 2000, Mace 2014), providing a more explicit economic justification for PAs as ecosystem service providers. However, because the relationships between politics, policy and society are dynamic, such 'narrowings' of the purpose of PAs may ultimately undermine their long-term socio-ecological resilience.

Before the advent of framings based on biodiversity and ecosystem services, PA policy had gained high-level political support on at least three occasions. The first time was during the colonial era when the 'wise-use' agenda gained prominence. This agenda was based on the idea that natural resources should be used for the greatest good in the long term, and resulted in the establishment of forest, game and watershed reserves by European colonial administrations and the US. During the interwar period a new conservation agenda began to take root, based on the value that "human conquest of nature carries with it a moral responsibility to ensure the survival of threatened life-forms" (Jepson \& Whittaker 2002). This was explicitly codified in the 1933 London Convention on African Wildlife and led to the widespread establishment of wildlife sanctuaries and national parks (Hingston 1931). PA policy attained high-level attention a third time when, in 1963, US President Johnson included nature-development as one of three pillars of his 'great society'. His policy combined values relating to amenity and the preservation of nature monuments, foregrounding the role of national and state parks to beautify nations and as sites of outdoor recreation for an increasingly affluent population with an increasing amount of leisure time (Whittaker 1976, Jepson 2017).

Wise-use, wildlife and nature development framings were firmly rooted in the foundational social movements of conservation (Jepson \& Canney 2003). They generated multiple forms of value for nature, people, society and economy and are still meaningful today. In this article we argue that the socio-ecological resilience of contemporary PAs can be strengthened by more effectively utilizing the full range of motivations and rationales for PA establishment. 
In support of our argument we present a protected area asset framework as a heuristic tool for re-stating the case for PAs in a way that is meaningful for citizens, politicians, investors and entrepreneurs. We frame PAs as a spatial asset class (= a distinct class of real estate), making explicit the forms of value they create and for whom, and the types of investment needed to generate value in the medium and long term. Our framework facilitates the identification of where value is located, and which PA assets are underperforming, degrading and/or at risk. Our framework is consistent with Mace's (2014) view that conservation policy is starting to move away from a strong utilitarian perspective (and back) to a more nuanced 'people and nature' view that recognises the importance of cultural institutions for developing resilience within the society-nature relationship. We hope the framework will support the design and development of a new generation of PA assessment metrics, decision support tools, planning processes and financing mechanisms. Further, we hope the language of assets and value will help conservationists communicate the value of PAs across different domains of society and policy, extending the range of professions and other groups who feel they have a stake in the future of PAs.

\section{Framing Protected Areas as Nature-based Assets}

\subsection{Framework positioning}

125 Our framework adopts a systems perspective and is rooted in conservation pragmatism: we believe that non-human forms of life have intrinsic value and a right to continued ecological existence. However, since the cognitive revolution 70,000 years ago we humans have lived a in a dual reality: the objective reality of rivers, mountains and animals and the intersubjective (or imagined) realties of money, gods, WWF, the Antarctic and so forth. These inter-subjective realities characterise human consciousness: they enable large scale collective action and have become ever more powerful over time giving rise to 'imagined orders' such as nations, empires and capitalism (see Harari 2014, 2016). Nature (biological) conservation is an 'imagined order' that blends values, emotion, rational science and collective action (e.g. PAs) in a coherent policy regime. To have influence, this imagined order must interact productively with multiple other imagined orders and not simply seek to align with the most dominant (e.g. neoliberal economics). 
137 Concepts of asset and value intertwine with multiple inter-subjective realities, creating opportunities for positive alignments between the desire to protect, manage and restore biophysical entities and the imaged orders that characterise, structure and shape societies. In short, we posit that if PAs are framed as assets that generate value within the inter-subjective realties that govern collective action there is a greater likelihood that investment will flow into conserving the biophysical assets they protect.

2.2 'Assets' in the context of PA policy.

144 The term 'asset' is widely used in economics and finance (and in everyday language). In economics it generally refers to property, funds or other resources that are owned by an entity and which can be transferred (Parkin 2005). In finance and investment, assets are things (such as securities, land and buildings) that can be contractually purchased to generate income. In popular culture, an asset is generally understood as a useful or valuable attribute of a person or group ("her quick reflexes were an asset for the team") (Simpson and Weiner 1989). In economics and finance, assets generate financial (monetary) value; in wider society assets are understood as generating value in terms of action possibilities (affordances) that may be nonmonetizable.

Taking the above into account, we define nature-related assets as entities, attributes and relationships (see Tavle 1) that can be protected, managed and/or invested in to generate forms of value that can be captured by both humans and non-humans and the wider socioecological systems within which they live. For example, a PA investment to reintroduce a species will benefit the species concerned and the wider ecosystem (by restoring trophic cascades and associated ecological dynamics). Associated investments (e.g. in media expositions, research/visitor infrastructure) will also enable groups in society such as citizens, tourism enterprises, scientists, local communities and tourists to capture value from this investment.

Real estate is a category of asset that combines land and all the things (natural or humanmade) permanently attached to it. Real estate has a fixed and physical form and generates value over the long term in relation to its governance, economic and cultural context. For example, a city park is a public asset generating quality-of-life value for citizens. Likewise, farmland is a private asset generating income for the landowner, and common lands are community assets generating value for those with use rights. It follows that PAs can be grouped into categories based on their biophysical character and value-generating 
purpose/beneficiaries. For example: a mountain forest managed as a watershed reserve for a local municipality, a waterbird colony managed as a wildlife sanctuary to maintain bird populations in the wider landscape, and a scenic cove managed as state park for outdoor recreation. Such categories are, to an extent, evident in the various legal designation of PAs (national park, nature reserve, sustainable use reserve etc.), although these have largely been superseded in international policy by IUCN management categories (Ladle et al. 2011). The PAs within each category possess a variety of assets, made up of the specific biophysical, human, cultural, infrastructrual and institutional attributes located in or around the protected area (e.g. vistas, iconic species, bench-mark habitats, a ranger service, cave paintings, trail systems, eco-lodge concession, etc.). Some of these assets may apply to a group of protected areas (e.g. institutional assets such legal designations, a PA system design or a transboundary management agreement).

Critically, PA assets can be managed and invested in to generate multiple forms of value. Here, PA asset stewardship refers to systematic practices to protect, maintain, deploy, upgrade and divest of assets throughout their life cycle in an effective manner. We prefer the term asset stewardship over the more established term asset management because the latter has been somewhat discredited by short-termism in the financial sector. Asset stewardship emphasises long-term asset protection and management and is more consistent with practices of infrastructure, public and enterprise asset management in the corporate and public sectors. There are enormous potential benefits of applying the principles and practice of asset stewardship to PA systems: such an approach could complement and extend existing scientific practices of reserve design and optimisation (e.g. Christensen et al. 2009; Pressey et al. 1993) and auditing management effectiveness (Hockings et al. 2006). For example, if there is a limited political opportunity for establishing and/or implementing PA policy, a framework that demonstrates societal-value generation would enable better alignment of science-based PA proposals with political imperatives.

\subsection{Natural assets vis-a-vis natural capital}

Our concept of PA assets (and more broadly natural assets) is more expansive than that of natural capital. Economists view natural capital as 'stocks': either non-renewable stocks such as minerals, or renewable stocks such as timber and fish. However, while stocks can also be assets, assets can be more than stocks. This is because the value that an asset generates over time can be measured in a variety of ways. Thus, natural capital is nested within the broader concept of natural asset. Natural assets generate (or can be managed to generate) multiple 
202

203

204

205

206

207

208

209

210

211

212

213

214

215

216

217

218

219

220

221

222

223

224

forms of value that emerge in relation to their socio-ecological context. Some of these forms of value can be converted into standardised units that can be used in balance sheet reporting, monetary valuation and the creation of markets. This is the natural capital component of nature. However, much of the value generated by nature relates to non-commercial dimensions and is unsuited to monetisation (Martín-López et al. 2007; Nunes and van den Bergh 2001), yet is still relatively easy to communicate, represent and understand. These broader forms of value are included in everyday usage of the term asset. Put another way, a natural capital approach frames the purpose of PA policy in terms of assuring stocks of natural resources and ecosystem processes to support human societies, In contrast a natural asset approach frames the purpose of PA policy in terms of creating the conditions for human societies to flourish and the biosphere to be maintained (or recover).

Within the natural asset frame we identify two broad categories of PA (Figure 1): i) those that can be managed using the logics of natural capital, and; ii) those that are 'cultural natures' i.e. their natural attributes emerge through the interaction of biophysical assets with cultural myths and associated practices (e.g. media representations of iconic species and landscapes). Importantly, PAs that embody 'cultural natures' (e.g. wilderness, scenic beauty, traditional culture) can be managed as an asset portfolio, but cannot be aggregated and substituted in the same way as capital (Fig. 1). This distinction is at the core of the biodiversity offsetting debate: it is difficult to offset like-for-like and/or convert land based natural assets into monetary units that can be used to purchase alternative natural capital (Apostolopoulou and Adams 2015; Bonneuil 2015; Devictor 2015).

Figure 1: The Natural Asset frame embraces and connects ideational elements from both natural capital and cultural nature's frames. 


\section{Natural Asset Frame}

\begin{tabular}{|c|c|}
\hline Cultural natures & Natural capital \\
\hline $\begin{array}{l}\text { Nature-based cultural attributes } \\
\text { \& dynamics }\end{array}$ & $\begin{array}{c}\text { Natural resource stocks \& } \\
\text { processes }\end{array}$ \\
\hline $\begin{array}{c}\text { Coproduced by human cultural } \\
\text { engagements }\end{array}$ & $\begin{array}{l}\text { Self-regulating \& renewing } \\
\text { without human intervention }\end{array}$ \\
\hline $\begin{array}{l}\text { Convertible to categories \& } \\
\text { indices }\end{array}$ & $\begin{array}{l}\text { Convertible to standardised } \\
\text { 'balance sheet' units }\end{array}$ \\
\hline $\begin{array}{l}\text { Situated, can be managed as a } \\
\text { portfolio }\end{array}$ & $\begin{array}{c}\text { Can be aggregated and } \\
\text { substituted }\end{array}$ \\
\hline $\begin{array}{l}\text { Amenable to development \& } \\
\text { quality-of-life economies }\end{array}$ & $\begin{array}{c}\text { Amenable to commodification \& } \\
\text { creation of markets }\end{array}$ \\
\hline $\begin{array}{l}\text { Conserving \& developing nature- } \\
\text { based attributes that enrich } \\
\text { human culture \& collective well- } \\
\text { being (inc. non-human) }\end{array}$ & $\begin{array}{l}\text { Assuring stocks of natural } \\
\text { resources \& ecosystem services } \\
\text { to support human societies }\end{array}$ \\
\hline $\begin{array}{c}\text { Foregrounds long-term value } \\
\text { generation in diverse forms that } \\
\text { may change over time }\end{array}$ & $\begin{array}{l}\text { Foregrounds growth \& } \\
\text { economic returns in short to } \\
\text { medium term }\end{array}$ \\
\hline
\end{tabular}

2.4 Conceptions of value

227 Two broad conceptions of value dominate the conservation literature: i) intrinsic or non228 anthropocentric value, generally referring to species, habitats and nature having value independent of human needs (Vucetich et al. 2015), and; ii) instrumental or anthropocentric values, referring to the benefits that nature provides to people and societies. These ethical positions underpin an enduring schism within conservation characterised as preservationist vs. protectionism - currently being revisited in the so called 'new conservation' debate (cf. Spash and Aslaksen 2015).

234 Our PA asset framework goes beyond such value dichotomies and adopts a relational approach that considers value as an emergent property of interactions between entities and systems. Here, 'entity' refers to both human and non-human 'things', including non-human life-forms, ecological process and socio-constructs, the identity of which may take different forms in different relational systems. Value long ago became standardised as money in trade relations (Harari 2014), but in many other spheres of life this is not the case. Simply put, value is an assessment of worth, usefulness or importance of something which depends on context. Relational approaches understand value as being composed of 'spatially and 242 historically contingent relationships' (Tadaki et al,. 2017 p7) that connect people, society and nature. Such conceptions of value gaining attention in policy circles and can be summarised as 'good quality of life' values (Chan et al. 2016; Díaz et al. 2015). These include eudaimonic values: forms of value that support a good life and self-actualisation and that contribute to psychological and social well being (Deci and Ryan 2008). 
248 In the context of our asset framework, nature-based value can be understood as a package of 249 affordances or action possibilities (Gibson 1977) that emerge from the interplay between the 250 biophysical reality and the interest groups perceiving that reality. Relational forms of value 251 based on biophysical characteristics (e.g. a waterfall) are always situated - in terms of 252 locality, culture and the identity and agendas of those interacting with the characteristic. This 253 relational understanding of value underpins our conception of natural assets as biophysical 254 characteristics that are (or become) valued in relation to human survival, commerce, science, culture and so forth. Put another way, value is a relational attribute arising from practices of engaging with nature (and PAs) and consequently takes different forms in different domains of life. For example, a landscape may be topographically complex, but this cannot be considered as the natural asset without reference to a culture that appreciates and values 'rugged' lands. In this respect it should be noted that Europeans considered mountain regions (e.g. the Alps) ugly and dangerous before the pervading cultural influence of the late $18^{\text {th }}$ Century Romanticism movement (Nicolson 1997). When topographically complex landscapes interact with cultures that have been influenced by romanticism, traits of ruggedness become the asset of 'scenic beauty', generating value in the form of aesthetic appreciation (and possibly tourist revenue). Likewise, a forest containing trees with hard wood and straight trunks becomes, in relation to a culture of resource extraction, the asset of 'timber', generating value in the form of employment and money. Species richness or endemism become, in relation to practices of scientific assessment, the asset of 'biodiversity' generating value in the form of, for example,functioning ecosystems and scientific knowledge production.

Relational approaches to value underpin three additional value concepts that are important in decision making (Tadaki et al. 2017). The first is value as a magnitude or preference, which is prominent in the economic tradition of monetary valuation. However, preference-based valuation can also be conducted in deliberative forums and our typologies of PA assets, value-generating practices and forms of value (Tables $1 \&$ 2) are intended to support such approaches. The second is value as individual or collective aspirations. Such values structure priorities and are evident in value generating practices (e.g. outdoor recreation and wellbeing) as well as the foundational social values of the conservation movement that created the 
is value as a contribution to a goal. In our framework this conception of PA value is captured in forms of value such as nation building, delivery on mission and policy targets

Protected areas can be a focus for investment in the creation, protection and value-generating potential of bio-physical assets. However, their value generating potential will be maximised if PA managers consider: i) how the intended beneficiary publics relate to and engage with nature, and; ii) support and stimulate practices of engaging with PAs that create opportunities for people to capture value from the PA's assets (see also Chan et al. 2016).

\section{The PA Asset Framework}

Our asset framework comprises three principal components: i) what protected area assets are present or absent in a PA; ii) how forms of value are generated by these assets and; iii) the domains of society where beneficiaries capture (or have the potential to capture) value from PA assets. Draft typologies within each of these components were developed from an analysis of the history of conservation and PA policy.

We consider PAs as spatial asset created through investments in five types of PA assets (Table 1; Supplementary Materials). The specific combination of assets associated with a PA varies in relation to bioregion, country, and era of establishment. Some institutional assets (e.g. legal frameworks and designations) are externally formulated and governed and may therefore be associated with multiple PAs. The interactions between different PA assets will generate different combinations of value that can be captured by different groups in different domains of society. For instance, in forest, game, biodiversity and watershed protection reserves the biophysical assets (trees, wildlife, species, hydrological processes) exist independently of human culture. Nevertheless, such assets can be developed as a 'stock' of renewable resources, ecosystem services or biodiversity through investments in the development of associated human assets (e.g. resource scientists, foresters), infrastructure (roads, nurseries) and institutional assets (e.g. regulations, certification).

Table 1: Five types of PA assets that interact to construct the overall PA asset (see supplementary materials for detailed specification of sub-types)

\begin{tabular}{lll}
\hline \hline Asset Type & Descriptor & Sub-types \\
\hline Biophysical & the biotic and abiotic entities and & Scenic beauty : nat. features : \\
assets & attributes present within the nat. spectacles : renewable nat. & resources : Non-renewable nat. \\
& boundaries of the PA. & resources : species assets : \\
& & ecosystem assets : agricultural \& \\
\hline
\end{tabular}




\begin{tabular}{|c|c|c|}
\hline & & fisheries resources \\
\hline Human Assets & $\begin{array}{l}\text { the groups of people associated with } \\
\text { the protected area who have } \\
\text { knowledge and/or skills that enable } \\
\text { the conservation of PA assets and the } \\
\text { generation and capture of value from } \\
\text { these assets }\end{array}$ & $\begin{array}{l}\text { PA technical staff : rangers : } \\
\text { guides : volunteers : researchers : } \\
\text { trad. peoples }\end{array}$ \\
\hline $\begin{array}{l}\text { Infrastructure } \\
\text { Assets }\end{array}$ & $\begin{array}{l}\text { the facilities that have been } \\
\text { constructed in, around or to the PA } \\
\text { that enable value generation and } \\
\text { capture }\end{array}$ & $\begin{array}{l}\text { Private \& public transport access } \\
: \quad \text { visitor infrastructure: PA } \\
\text { management\& research } \\
\text { infrastructure : public utilities : } \\
\text { emergency services : built } \\
\text { monuments and artworks }\end{array}$ \\
\hline $\begin{array}{l}\text { Institutional } \\
\text { Assets }\end{array}$ & $\begin{array}{l}\text { the legal frameworks that construct a } \\
P A \text { and the structures and } \\
\text { contractual agreements that } \\
\text { conserve assets and enable value } \\
\text { generation and capture from them. }\end{array}$ & $\begin{array}{ll}\text { Conservation } & \text { designations: } \\
\text { decision making } & \text { structures : } \\
\text { partnership/ } & \text { commercial } \\
\text { agreements : budget } & \end{array}$ \\
\hline Cultural Assets & $\begin{array}{l}\text { the interactions between the PA and } \\
\text { wider cultural practices and } \\
\text { narratives that create a public } \\
\text { identity for the } P A\end{array}$ & $\begin{array}{l}\text { Brand/emblems : creative } \\
\text { interpretations : cultural events : } \\
\text { media portrayals : myths \& } \\
\text { legends : recreational clubs : } \\
\text { cultural heritage }\end{array}$ \\
\hline
\end{tabular}

307 In national and state parks, nature monuments and wildlife sanctuaries, important biophysical assets are co-produced through interactions with culture (see above) and cannot be conceptualized as stocks. Such co-production of assets is explicit in our framework, where value is a relational attribute arising from practices of engaging with PA assets (directly or indirectly). As a consequence PA-generated value (worth, importance, usefulness) manifests in different forms in different domains of life.

We consider four main domains of society where PA value is generated and can be captured: i) every-day life; ii) professional and organisational life; iii) politics and diplomacy; iv) economy and enterprise. Practices in each of these domains interact with PAs to generate forms of value for the person, group or entity involved (Table 2). For example, citizens capture life-quality values such as aesthetic expression, a sense of wonder and physical wellbeing from biophysical assets such as scenic beauty, iconic species and natural spectacles.

319 These values can be captured through practices such day-tripping, trekking and watching wildlife documentaries. Likewise, political leaders potentially capture diplomatic value from PAs through demonstrating leadership in areas international policy (e.g. Brazil's hosting of 
the 1992 Earth summit and subsequent expansion of its PA estate) and nation building value through practices of 'logoizing' territory (Anderson 2016) to generate a sense of collective pride and identity with a nation, state or region. Examples include US national parks in the $19^{\text {th }}$ century (Nash 2014), UK national parks post WWII (Sheail 1975) and tiger reserves in the context on Indian independence (Rangarajan 1996).

The three components of our framework (PA asset types: forms of value: domains of value generation/capture) synthesize the main dimensions of $20^{\text {th }}$ century PA policy and reformulate these for a $21^{\text {st }}$ century characterised by increasing and changing demands on land resources, a rising and more aspirational population with increasingly utilitarian values towards nature (Sagoff 2007), more 'hard-nosed' politicians and a new generation of conservation professionals attracted by a positive environmentalism. It is intended as a heuristic tool to take PA policy to the next step - from systematic practices of negating human impacts on nature to systematic practices of investing in natural value over the long term.

Table 2. Broad domains of society where value generating practices enable the 'capture' of different forms of value. The examples are illustrative.

\begin{tabular}{|c|c|}
\hline Value generating practice & Form of value captured \\
\hline \multicolumn{2}{|c|}{$\begin{array}{l}\text { 3.1 Domain of Everyday life: value captured by individuals families, friends and } \\
\text { groups }\end{array}$} \\
\hline $\begin{array}{l}\text { Day-tripping (e.g. picnicking, roaming, } \\
\text { relaxing) }\end{array}$ & $\begin{array}{l}\text { Sociality (e.g. camaraderie, family, } \\
\text { friendships) }\end{array}$ \\
\hline $\begin{array}{l}\text { Touring (e.g. sight-seeing, visiting, } \\
\text { recreating etc.) }\end{array}$ & $\begin{array}{l}\text { Physical \& mental well-being (e.g. health, } \\
\text { fitness, stress management) }\end{array}$ \\
\hline $\begin{array}{l}\text { Field-sports (e.g. hunting, fishing, bird- } \\
\text { watching, wildlife photography) }\end{array}$ & $\begin{array}{l}\text { Meaning \& purpose (e.g. participation in a } \\
\text { cause) }\end{array}$ \\
\hline $\begin{array}{l}\text { Adventure sports (e.g. skiing, mountain- } \\
\text { biking, climbing, para-gliding) }\end{array}$ & $\begin{array}{l}\text { Self-actualisation (e.g. spiritual, moral, } \\
\text { aesthetic expression and development) }\end{array}$ \\
\hline $\begin{array}{l}\text { Volunteering and activism (e.g. } \\
\text { management, citizen science, guiding, } \\
\text { campaigning) }\end{array}$ & $\begin{array}{l}\text { Adventure \& achievement (skill } \\
\text { development, succeeding in endeavours, self- } \\
\text { sufficiency) }\end{array}$ \\
\hline $\begin{array}{l}\text { Edutainment (e.g. viewing nature } \\
\text { documentaries, reading, gaming) }\end{array}$ & $\begin{array}{l}\text { Collective identity (e.g. sense of place, } \\
\text { collective identity) }\end{array}$ \\
\hline $\begin{array}{l}\text { Sustainable resource management (e.g. } \\
\text { environmentally-friendly-agriculture) }\end{array}$ & Traditional ways of living \\
\hline \multicolumn{2}{|c|}{$\begin{array}{l}\text { 3.2 Domain of Politics and Diplomacy: value captured by states, civil authorities \& } \\
\text { communities }\end{array}$} \\
\hline
\end{tabular}




\begin{tabular}{|c|c|}
\hline $\begin{array}{l}\text { Participation and leadership in } \\
\text { international regimes }\end{array}$ & $\begin{array}{l}\text { International standing, reputation and } \\
\text { leadership }\end{array}$ \\
\hline $\begin{array}{l}\text { Nation \& region building (e.g. using iconic } \\
\text { species or natural features to create a } \\
\text { collective sense of boundaries and identity } \\
\text { of nation) }\end{array}$ & $\begin{array}{l}\text { National/regional/local identity, pride, and } \\
\text { sense of allegiance. }\end{array}$ \\
\hline $\begin{array}{l}\text { Stories of nation (e.g.: promoting nature } \\
\text { and nature-based practices to create the } \\
\text { myths, icons and history that produce the } \\
\text { imagined reality of states, regions ) }\end{array}$ & $\begin{array}{l}\text { National security (e.g. governance presence } \\
\text { in remote areas, boarder control) }\end{array}$ \\
\hline $\begin{array}{l}\text { Conservation projects and trans-boundary } \\
\text { management agreements in remote regions }\end{array}$ & Political stability \\
\hline $\begin{array}{l}\text { Governance partnerships involving civil- } \\
\text { society actors and less-represented groups. }\end{array}$ & \\
\hline $\begin{array}{l}\text { Ecosystem service protection \& restoration } \\
\text { of ecosystem services (e.g. watershed } \\
\text { protection, reforestation) }\end{array}$ & Social \& economic resilience \\
\hline $\begin{array}{l}\text { Tourism development (e.g. marketing, } \\
\text { transport infra-structure etc.) }\end{array}$ & $\begin{array}{l}\text { Inward investment through for e.g. foreign } \\
\text { exchange and international aid flows. }\end{array}$ \\
\hline \multicolumn{2}{|c|}{$\begin{array}{l}\text { 3.3 Domain or Professional and Organisational life: policy, scientific, management and } \\
\text { other professions and the NGOs Government agencies, University departments and } \\
\text { consultancies they work for or with. }\end{array}$} \\
\hline PA policy and planning & $\begin{array}{l}\text { Distinct technical domain and 'territory' of } \\
\text { responsibility }\end{array}$ \\
\hline Lobbying \& advocacy & $\begin{array}{l}\text { Policy access and influence at multiple } \\
\text { levels and across different sectors }\end{array}$ \\
\hline Research (scientific, policy) & New products and technologies \\
\hline $\begin{array}{l}\text { Inventory \& monitoring (field surveys, } \\
\text { remote sensing, bio-prospecting) }\end{array}$ & $\begin{array}{l}\text { Applied knowledge and evidence (e.g. } \\
\text { policy \& management) }\end{array}$ \\
\hline Conservation management projects & $\begin{array}{l}\text { Organisation mission, purpose, targets \& } \\
\text { reputation }\end{array}$ \\
\hline Campaigning and public engagement & Constituency building and mobilization \\
\hline $\begin{array}{l}\text { Public Service provision (health, } \\
\text { recreation, etc.) }\end{array}$ & Cost effective and inclusive policy delivery \\
\hline \multirow{2}{*}{$\begin{array}{l}\text { Fund-raising \& income generation (e.g. } \\
\text { grants, fees, licences) }\end{array}$} & Operational funds \\
\hline & $\begin{array}{l}\text { Professional careers and esteem (status, } \\
\text { access, influence) }\end{array}$ \\
\hline \multicolumn{2}{|l|}{ 3.4 Domain of Economy and enterprise } \\
\hline $\begin{array}{l}\text { Operating concessions (e.g. visitor, } \\
\text { transport resource extraction etc.) }\end{array}$ & Profit and jobs \\
\hline
\end{tabular}




\begin{tabular}{|l|l|}
\hline $\begin{array}{l}\text { Constructing and maintaining PA infra- } \\
\text { structure (e.g. trails, centres, car parks etc). }\end{array}$ & $\begin{array}{l}\text { Contracts for local companies and } \\
\text { tradesmen }\end{array}$ \\
\hline $\begin{array}{l}\text { Providing visitor services (e.g. guest } \\
\text { houses, restaurants, guiding, shops) }\end{array}$ & Small-enterprise opportunities \\
\hline PA branding and marketing & Markets-for-local produce \\
\hline Financing instruments & $\begin{array}{l}\text { Urban-rural flows (eg. of capital and } \\
\text { entrepreneurial and creative ideas and } \\
\text { people) }\end{array}$ \\
\hline
\end{tabular}

\section{Protected area asset stewardship}

The framework explicitly recognizes the important dynamic that exists between those who set protected area policy and those who can capture (or co-produce) the forms of value that protected area assets can generate. Its application is centred around four fundamental questions:

1) What forms of value are PA assets currently generating and for whom?

2) What forms of value could be generated from PA assets and for whom?

3) What forms of value are wanted, what are the trade-offs, andwho decides?

4) What forms of investments are needed to ensure that intended 'publics' can capture investment value?

Providing answers to these questions will enhance transparency and democratic accountably in PA policy and help structure investment decisions. It should be noted that investors may seek returns in a variety of forms, including financial returns (e.g. a treasury or corporation investing in parks to generate ecotourism revenues), scientific and policy returns (e.g. a research council investing in ecological stations to generate policy-relevant knowledge), social returns (e.g. a municipality investing in reserves to generate recreation and health benefits), or ethical returns (e.g. a conservation NGO investing in reserves to save the last population of an evolutionary distinct species).

357 The framework tool supports two key components of PA asset stewardship: 1) system (portfolio) design, review and management, and; 2) investment and finance.

4.1 PA system design, review and management.

Most nations now have a protected area system. The competent government authority and its partners must develop policy and strategy concerning, among other things, where to acquire new reserves, whether or not to proceed with PADDD proposals, securing and allocating the 
necessary human and finical resources to manage PAs, and aligning PA policy with wider policy imperatives. At a system level the primary decision-support frameworks available to PA policy makers are PA typologies (those specified in national law and the IUCN management and governance categories (Dudley 2008)), systematic conservation planning principles and software (Ball et al. 2009; Margules and Pressey 2000) and civil societygenerated prioritisation schemes such as Key Biodiversity Areas (Eken et al. 2004). These support PA policy based on guarding against the "loss of ecosystems, species and other valued aspects of the natural environment" (Pressey et al. 2015) and regulating human activities in and around protected areas. Newer, frameworks such as the UK National Ecosystem Assessment which produce metrics of ecosystem service value support policy that is less defensive and more focused on conserving and investing in biophysical assets to generate value for society and the biosphere (NEA 2011). Our PA asset framework continues and extends this thinking.

Operationalising the asset framework at the PA system level requires that PA units are classified into different asset categories grouped according to primary value generating purpose(s). Prior to ratification of the CBD and the move towards aggregating PA purpose in terms of biodiversity conservation, such disaggregation was the norm in many countries (and still is in some). Given this, PAs can potentially be classified into two broad asset categories by reformulating established categories of resource reserves and parks/monuments/sanctuaries. The former would have utility purpose and be managed to generate profit, support local livelihoods and/or the ecosystem functions necessary to support economic productivity and protect property. These PAs could be divided into sub-categories of renewable natural resource, biodiversity, and ecosystem service reserves and managed using the logics of natural capital and economics.

The purpose of the parks/monuments/sanctuaries category would be to create interactions between the five main asset categories (Table 1) and wider culture and society to generate heritage, identity, recreation, scientific and self-actualisation forms of value that support quality lives. Such PAs could be divided into sub-categories of national/state/municipal parks, wildlife sanctuaries, nature monuments, scientific/experimental reserves and cultural land/seascapes and could be managed using public good logics. Investments in this second PA category could also generate economic value because such value is captured through tourism, recreation and entertainment practices that create numerous enterprise opportunities given a supportive investment and policy environment. 
396 Competent policy agencies prefer to implement regulations based on quantitative criteria

397 (Noss 1990). A further step would thus be to develop indicators of protected area assets with existing or potential value generating properties that support inventory, assessment and monitoring (see extended asset typology in Supplementary Materials). Indicators of some

400

401

402

403

404

405

406

407

408

409

410

411

412

413

414

415

416

417

418

419

420

421

422

423

424 sub-categories are already available (e.g. ecosystem assets in the guise of ecosystem services). In contrast, indicators for other categories (e.g. public access, public utilities, natural spectacles and iconic species) generally do not exist, but could potentially be generated and mapped using geo-spatial techniques and big data analytics (Ladle et al. 2016).

Likewise, data on human assets, if not already available, could be generated through surveys of park managers.

At the PA unit level the management plan represents a key institutional asset with the potential to underpin PA investment. Good practice guidelines (e.g. Worboys et al. 2001) (and most legislation) require that management plans are prepared and approved for each significant PA unit. However, they are often prepared by consultants and often follow a formulaic structure that strongly highlights protection. Our asset framework offers a complementary approach and a typology that can be used as a guide to identify PA assets and formulate responses to the four key questions (above). This is likely to broaden local buy-in, support deliberation on priorities and trade-offs, and add an investment plan component to the traditional PA management plan.

\subsection{PA Investment and finance}

It is well known that protected areas, and conservation more generally, are underfunded (McCarthy et al. 2012). A common response to this issue is to highlight the rates of biodiversity loss and the failure to meet targets and call for increased 'assistance' from development or other public funds (e.g. Waldron et al. 2013). Our asset framework offers a complementary investment approach and proposition. The world is awash with capital but typical returns on investments are historically low. This, in combination with ideas of impact investing, is generating a demand for conservation investment products. A 2014 Naturevest survey found that in the next 5-years private investors intend to deploy $\$ 5.6$ billion in conservation impact investments (where returns are part financial and part measurable social and environmental impact (NatureVest 2014)).

Mobilising private capital managed and/or owned by investment institutions and individuals requires the development of investment products such as green bonds and funds. A bond is a 
debt security (IOU) issued by a government body or corporation and is based on the premise that investment will enable (or justify) the principal being repaid with interest at the end of the bond period. Investment funds come in various forms, but typically involve numerous investors buying shares in a 'themed' group of securities (a guarantee that something will be repaid). The development of PA investment products would therefore require PAs to be 'bundled' into groups to meet the required investment scale and to provide returns that are meaningful to capital markets. Our asset framework supports such an approach. For example, while a group of municipalities are unlikely to issue a green bond to finance the goal of better biodiversity protection in their region, they may be able to attract interest in a bond structured to invest in PA infrastructure and human assets that generate measurable watershed, public health, and recreation economy value for their citizens. An alternative model would be to 'bundle' such PA investments with other green infrastructure investments, such as decarbonized transportation or refurbishment of power grids, thus easing the demand on dedicated PA budgets.

Once formalised, a PA asset approach would create the capacity to optimize PA assets (as sites or networks) in terms of their spatial location, investment profile, and the forms of value they generate over time. It would also support and extend the programme of work on PA management effectiveness (Coad et al. 2015) through providing a framework to assess the social, economic and cultural benefits of PAs. Traditional sources of operational and capital funding, particularly from governments, development aid and conservation organisations, have been insufficient to assure PA assets and appear to be diminishing (Emerton et al. 2006). Profiling and grouping PAs according to their biophysical and other assets and the forms of value they generate for different groups has the potential to attract a wider array of investments, from old, current, and new sources.

\section{Discussion}

Our aim in this article was to apply financial concepts of asset management and stewardship to PA policy. Our asset framework is currently heuristic, and is largely intended as a vehicle to restate the case for PAs in terms that are meaningful and useful to multiple policy, public and investor constituencies. Application of the asset framework offers the prospect of a 'situated' PA policy where biophysical assets are matched with the needs of nature and 
society across multiple scales and attract investment from multiple sources in order to maximise value generation over specified time periods.

Some conservationists may question why another policy framework is needed? After all, the biodiversity frame introduced a generation ago is now deeply embedded in public policy and the newer ecosystem service frame, which articulates the benefits humans receive from biodiversity and ecosystems, has gained considerable traction in science and policy. Further, the adoption of this, or any other new framework, would change institutional dynamics and this might produce unforeseen or undesirable consequences. In response, we would make three main points:

First, the world's protected area estate is now so extensive that it merits a specific framework that reflects the policy heritage of PAs and generates a case for investment that is simultaneously popular and technocratic. The ES approach intersects with our asset framework, but is designed as a tool for broader socio-ecological assessments and is increasingly applied using zonal mapping approaches (e.g. Maes et al. 2012; Schägner et al. 2013). Our asset framework emphasizes azonal land parcels (PAs) that are culturally constructed to varying degrees and supports PA policy implementation across multiple governance levels - from national PA system design to district level management planning.

Second, our framework is grounded in the growing scientific literature on environmental valuation. The adoption of the ES approach in the Millennium Ecosystem Assessment (MEA 2005) and The Economics of Ecosystems and Biodiversity (www.teebweb.org) report prompted and shaped a proliferation of research on nature-based values and valuation (see Potschin and Haines-Young 2011, Fig. 1). Cultural ES have proved difficult to conceptualise and formalise and as a result their inclusion in decision making is still the exception rather than the rule. Relational values are becoming an important pillar of future research on cultural ES (Hirons et al. 2016): by conceptualizing such values in relation to PAs and highlighting the importance of 'practices of engagement' our asset framework offers a valuable point of convergence between the ES approach and PA policy.

Third, trade-offs are central to the conduct of politics, policy and society. Decision-makers regularly re-examine trade-offs and, in cases where land is involved and economies are weak, there is always a risk that nature conservation will lose out. Our framework offers a systematic means for multiple interest group to assess and communicate the value of a PA and thereby extend political deliberation on trade-offs beyond simple economic metrics. In 
491

492

493

494

495

496

497

498

499

500

501

502

503

504

505

506

507

508

509

510

511

512

513

514

515

516

517

518

519

520

521

addition, our framework supports democratic engagement in discussions on how best to balance trade-offs that arise from optimising investments in different assets.

Finally, the notion of assets - PA and natural - may provide a term around which the conservation movement can unify. Debates over ideology and ethics are necessary and important, but can become counterproductive when they descend into disciplinary struggles over the framing of policy. The days when ecology and conservation biology were the preeminent disciplines informing international conservation policy are over, and the proactive engagement of the economic and social sciences should be welcomed. Nevertheless, economic framings of nature as capital and ecosystems as service providers alienate many conservation professionals and activists. The natural environment is multifaceted and as such requires multifaceted policy. Adopting the term natural assets and framing it in a relational manner offers the prospect of more collegiate interactions between disciplines and worldviews leading to more effective policy.

Continuing this theme, an emerging challenge is how to address the growing disconnect between the technocratic approaches of those developing international environmental policy and the needs, values and motivations of the publics and grounded-professionals who engage with and manage nature in their everyday lives. This is a wider issue for democratic governance as indicated by the 2016 Brexit vote and Trump US presidential campaign. The concept of natural and PA assets rooted in life-quality values offers a way to reconnect nature policy with people. After all, the Earth is neither capital nor a resource: it is an asset that sustains life. Investing in protecting, managing, restoring our planet's natural assets to improve the life quality of sapiens and other life forms is surely the over-arching goal of environmental policy.

\section{Acknowledgements}

We thank the 183 protected area professionals who responded to our online survey of initial asset and value categories and to Mark Hockings, Eric Gómez-Baggethun, Nathalie Page, Elenor Lewis, Dexiang Cheng, Barbara Resende de Moraes, Michael Vies who have either conducted test applications or commented on this framework. Their contributions have been invaluable for its development. The research was supported with grants from WWF-UK, The Luc Hoffmann Institute, and The Woodchester Trust and funding under Brazilian National 
Council for Scientific and Technological Development CNPq-PVE Grant (No: 400325/20144) and CNPq- Universal grant (No: 448966/2014-0).

\section{References}

Apostolopoulou, E., Adams, W.M., 2015. Biodiversity offsetting and conservation: reframing nature to save it. Oryx, doi:10.1017/S0030605315000782

Ball, I.R., Possingham, H.P., Watts, M., 2009. Marxan and relatives: software for spatial conservation prioritisation. Spatial conservation prioritisation: quantitative methods and computational tools. Oxford University Press, Oxford, 185-195.

Bernard, E., PENNAPenna, L., Araújo, E., 2014. Downgrading, Downsizing, Degazettement, and Reclassification of Protected Areas in Brazil. Conservation Biology 28, 939-950.

Bonneuil, C., 2015. Tell me where you come from, I will tell you who you are: A genealogy of biodiversity offsetting mechanisms in historical context. Biological Conservation 192, $485-491$.

Chan, K.M., Balvanera, P., Benessaiah, K., Chapman, M., Díaz, S., Gómez-Baggethun, E., Gould, R., Hannahs, N., Jax, K., Klain, S., 2016. Opinion: Why protect nature? Rethinking values and the environment. Proceedings of the National Academy of Sciences 113, 14621465.

Christensen, V., Ferdaña, Z., Steenbeek, J., 2009. Spatial optimization of protected area placement incorporating ecological, social and economical criteria. Ecological Modelling 220, 2583-2593.

Coad, L., Leverington, F., Knights, K., Geldmann, J., Eassom, A., Kapos, V., Kingston, N., de Lima, M., Zamora, C., Cuardros, I., 2015. Towards the assessment of protected area management effectiveness. Royal Society of London. Philosophical Transactions B. Biological Sciences 273, 20140281.

Deci, E.L., Ryan, R.M., 2008. Hedonia, eudaimonia, and well-being: An introduction. Journal of Happiness Studies 9, 1-11.

Devictor, V., 2015. When conservation challenges biodiversity offsetting. Biological Conservation 192, 483-484.

Díaz, S., Demissew, S., Carabias, J., Joly, C., Lonsdale, M., Ash, N., Larigauderie, A., Adhikari, J.R., Arico, S., Báldi, A., 2015. The IPBES Conceptual Framework-connecting nature and people. Current Opinion in Environmental Sustainability 14, 1-16.

Donohue, I., Hillebrand, H., Montoya, J.M., Petchey, O.L., Pimm, S.L., Fowler, M.S., Healy, K., Jackson, A.L., Lurgi, M., McClean, D., 2016. Navigating the complexity of ecological stability. Ecology Letters 19, 1172-1185.

Dudley, N., 2008. Guidelines for applying protected area management categories. IUCN, Gland, Switzerland. 
Eken, G., Bennun, L., Brooks, T.M., Darwall, W., Fishpool, L.D., Foster, M., Knox, D., Langhammer, P., Matiku, P., Radford, E., 2004. Key biodiversity areas as site conservation targets. BioScience 54, 1110-1118.

Emerton, L., Bishop, J., Thomas, L., 2006. Sustainable financing of protected areas: A global review of challenges and options. IUCN, Gland.

Geldmann, J., Joppa, L.N., Burgess, N.D., 2014. Mapping Change in Human Pressure Globally on Land and within Protected Areas. Conservation Biology, 28, 1604-1616.

Gibson, J.J., 1977. The theory of affordances, In Perceiving, Acting, and Knowing: Toward an Ecological Psychology. eds R. Shaw, J. Bransford, pp. 67-82. Lawrence Erlbaum Associates, Hilldale, USA.

Grove, R.H., 1992. Origins of Western Environmentalism. Scientific American 267, 4247.Harari, Y.N., 2014. Sapiens: A brief history of humankind. Random House, London.

Harari, Y.N., 2014. Sapiens: A brief history of humankind. Random House.

Harari, Y.N., 2016. Homo Deus: A brief history of tomorrow. Random House.

Hingston, R. W.G., 1931 Proposed British national parks for Africa. Geographical Journal 825, 401-422. Hirons, M., Comberti, C., Dunford, R., 2016. Valuing Cultural Ecosystem Services. Annual Review of Environment and Resources, 41, 5.1-5.22.

Hockings, M., Stolton, S., Leverington, F., Dudley, N., Courrau, J., Valentine, P., 2006. Evaluating effectiveness: A framework for assessing management effectiveness of protected areas. IUCN, Galnd, Switzerland.

Jepson, P., 2017. Nature conservation, In International Encyclopaedia of Geography. AAEWiley Oxford, UK.

Jepson, P., Whittaker, R.J., 2002. Histories of protected areas: internationalisation of conservationist values and their adoption in the Netherlands Indies (Indonesia). Environment and History 2, 129-172.

Jepson, P. and Canney, S., 2003. Values-led conservation. Global Ecology and Biogeography, 12, 271-274.

Jepson, P., Whittaker, R.J., Lourie, S.A., 2011. The Shaping of the Global Protected Area Estate, In Conservation Biogeography. eds R.J. Ladle, R.J. Whittaker, pp. 93-135. WileyBlackwell, Oxford.

Ladle, R.J., Correia, R.A., Do, Y., Joo, G.-J., Malhado, A.C.M., Proulx, R., Roberge, J.-M., Jepson, P., 2016. Conservation culturomics. Frontiers in Ecology and the Environment 14, 269-275.

Ladle, R.J., Jepson, P., Gillson, L., 2011. Social values and conservation biogeography, In Conservation Biogeography. eds R.J. Ladle, R.J. Whittaker, pp. 13-30. Wiley-Blackwell, Oxford. 
Laurance, W.F., Balmford, A., 2013. Land use: a global map for road building. Nature 495, 308-309.

Mace, G.M., 2014. Whose conservation?.Science, 345, 1558-1560.

Maes, J., Egoh, B., Willemen, L., Liquete, C., Vihervaara, P., Schägner, J.P., Grizzetti, B., Drakou, E.G., La Notte, A., Zulian, G., 2012. Mapping ecosystem services for policy support and decision making in the European Union. Ecosystem Services 1, 31-39.

Margules, C.R., Pressey, R.L., 2000. Systematic conservation planning. Nature 405, 243-253.

Martín-López, B., Montes, C., Benayas, J., 2007. The non-economic motives behind the willingness to pay for biodiversity conservation. Biological Conservation 139, 67-82.

Mascia, M.B., Pailler, S., Krithivasan, R., Roshchanka, V., Burns, D., Mlotha, M.J., Murray, D.R., Peng, N., 2014. Protected area downgrading, downsizing, and degazettement (PADDD) in Africa, Asia, and Latin America and the Caribbean, 1900-2010. Biological Conservation $169,355-361$.

McCarthy, D.P., Donald, P.F., Scharlemann, J.P., Buchanan, G.M., Balmford, A., Green, J.M., Bennun, L.A., Burgess, N.D., Fishpool, L.D., Garnett, S.T., 2012. Financial costs of meeting global biodiversity conservation targets: current spending and unmet needs. Science 338, 946-949.

MEA, 2005. Millennium Ecosystem Assessment: Ecosystems and human well-being. Island Press, Washington, DC.

NatureVest, 2014. Investing in Conservation. A landscape assessment of an emerging market, Available http://www.naturevesttnc.org/pdf/InvestingInConservation_Report.pdf.

Norgaard, R.B., 2010. Ecosystem services: From eye-opening metaphor to complexity blinder.Ecological economics, 69, 1219-1227.

Noss, R.F., 1990. Indicators for monitoring biodiversity: a hierarchical approach. Conservation Biology, 4, 355-364.

Rangarajan, M. 1996. The Politics of ecology: the debate on wildlife and people in India, 1970-95. Economic and Political Weekly 2391-2409.

N.E.A., 2011. The UK National Ecosystem Assessment: Synthesis of Key Findings. UNEP WCMC, Cambridge, UK.

Nicolson, M.H., 1997. Mountain gloom and mountain glory: the development of the aesthetics of the infinite. University of Washington Press, Washington.

Noss, R.F., 1990. Indicators for monitoring biodiversity: a hierarchical approach.

Conservation Biology 4, 355-364. 
Nunes, P.A., van den Bergh, J.C., 2001. Economic valuation of biodiversity: sense or nonsense? Ecological Economics 39, 203-222.

Pack, S.M., Ferreira, M.N., Krithivasan, R., Murrow, J., Bernard, E., Mascia, M.B., 2016. Protected Area Downgrading, Downsizing, and Degazettement (PADDD) in the Amazon. Biological Conservation 197, 32-39.

Parkin, M., 2005. Economics. 5th edition. Addison Wesley, Boston.

Potschin, M.B., Haines-Young, R.H., 2011. Ecosystem services Exploring a geographical perspective. Progress in Physical Geography 35, 575-594.

Pressey, R., Humphries, C., Margules, C.R., Vane-Wright, R., Williams, P., 1993. Beyond opportunism: key principles for systematic reserve selection. Trends in Ecology \& Evolution 8, 124-128.

Pressey, R.L., Visconti, P., Ferraro, P.J., 2015. Making parks make a difference: poor alignment of policy, planning and management with protected-area impact, and ways forward. Phil. Trans. R. Soc. B 370, 20140280.

Sagoff, M., 2007.. 2008, The economyEconomy of the earth: philosophy, lawEarth: Philosophy, Law, and the environment.Environment. Cambridge University Press, CambridgeUK.

Schägner, J.P., Brander, L., Maes, J., Hartje, V., 2013. Mapping ecosystem services' values: Current practice and future prospects. Ecosystem Services 4, 33-46.

Sheail, J. 1975. Nature in Trust: The history of nature conservation in Britain, Blackie, Glasgow and London.

Simpson, J., Weiner, E.S., 1989. Oxford English dictionary. Clarendon Press, Oxford, UK.

Smith, P., Gregory, P.J., Van Vuuren, D., Obersteiner, M., Havlík, P., Rounsevell, M., Woods, J., Stehfest, E., Bellarby, J., 2010. Competition for land. Philosophical Transactions of the Royal Society B: Biological Sciences 365, 2941-2957.

Spash, C.L., Aslaksen, I., 2015. Re-establishing an ecological discourse in the policy debate over how to value ecosystems and biodiversity. Journal of environmental management 159 , $245-253$.

Swenson, J.J., Carter, C.E., Domec, J.-C., Delgado, C.I., 2011. Gold mining in the Peruvian Amazon: global prices, deforestation, and mercury imports. PloS one 6, e18875.

Symes, W.S., Rao, M., Mascia, M.B., Carrasco, L.R., 2015. Why do we lose protected areas? Factors influencing protected area downgrading, downsizing and degazettement in the tropics and subtropics. Global Change Biology 22, 656-665.

Tadaki, M., Sinner, J., Chan, K.M.A. 2017,. Making sense of environmental values: a typology of concepts. Ecology and Society. 22: 7

Vucetich, J.A., Bruskotter, J.T., Nelson, M.P., 2015. Evaluating whether nature's intrinsic value is an axiom of or anathema to conservation. Conservation Biology 29, 321-332. 
670 Waldron, A., Mooers, A.O., Miller, D.C., Nibbelink, N., Redding, D., Kuhn, T.S., Roberts, 671 J.T., Gittleman, J.L., 2013. Targeting global conservation funding to limit immediate 672 biodiversity declines. Proceedings of the National Academy of Sciences 110, 12144-12148.

673 Watson, J.E., Dudley, N., Segan, D.B., Hockings, M., 2014. The performance and potential 674 of protected areas. Nature 515, 67-73.

675 Whitaker, John, C. 1976. Striking a balance: Environment and natural resources policy in the 676 Nixon--Ford years. Washington D.C.: American Enterprise Institute for Public Policy 677 Research.

678 Winks, R.W., 2013. Laurance S. Rockefeller: catalyst for conservation. Island Press, 679 Washington DC.

680 Worboys, G., Lockwood, M., Lacy, T.D., 2001. Protected Area Management-Principles and 681 Practice. Oxford University Press, Oxford. 